\title{
METHOD OF DETERMINING PARAMETERS OF ELEMENTS OF WIND SOLAR SYSTEM OF AUTONOMOUS POWER SUPPLY
}

Gennady Nikitenko, Evgeny Konoplev, Vladimir Salpagarov, Pavel Konoplev

Stavropol State Agrarian University, Russia

nikitenko_gv@mail.ru, konoplev82@mail.ru

\begin{abstract}
The article presents a method for determining the parameters of elements of a combined autonomous power supply system that uses wind and solar energy. A gasoline generator is used as a backup power source. Energy from the wind generator and solar panels is accumulated in the storage system, or distributed through the inverter to the consumer. During periods of calm, alternative energy sources are supplied from the gasoline generator. The following parameters of elements of the combined system of autonomous power supply are determined, namely, a wind generator, solar panels, a gasoline generator, a storage system, and an inverter. The analysis of wind energy potential and solar energy potential on the example of the surroundings of the city of Stavropol is presented. As an object of power supply, an individual subsidiary farm was selected. The optimal parameters of the wind generator, the area of the solar panels and the capacity of the storage system for the selected power supply object are determined. The wind turbine is made as a wind propeller type with the profile from the installation of WE-3000, solar panels adopted as panel brand BSP 32-100F. Graphs are presented of average power generation by the wind turbine, solar panels, and the gasoline generator. The average annual generation of electricity from wind energy, which was $44.7 \%$, from solar energy $-42.9 \%$, from a gasoline generator $-12.4 \%$, is presented. The total power generation by the combined autonomous power supply system is $1950.7 \mathrm{kWh}$, solar panels $836.6 \mathrm{kWh}$, wind generator 872.2 , gasoline generator $241.9 \mathrm{kWh}$.
\end{abstract}

Keywords: sun, wind, energy.

\section{Introduction}

Autonomous power supply to consumers of the agro-industrial complex, remote from the electric networks, is one of the most prominent tasks. In this case, the reliability and continuity of power supply depend on the parameters of the elements of the autonomous power supply system. It is advisable to design combined wind and solar power supply systems, taking into account the wind and solar potential of energy in the intended location of the installation, the characteristics of consumers and load schedules. Based on the above, we propose a method for determining the parameters of a combined wind and solar autonomous power supply system for consumers of the agro-industrial complex on the example of an individual subsidiary farm.

When designing an autonomous power supply system and determining the parameters of its elements, it is necessary to consider the characteristics of consumers for whom it is intended. As an object of power supply, an individual subsidiary farm was selected, the characteristics of consumers of which are shown in Table 1.

Table 1

Parameters of individual household electric consumers

\begin{tabular}{|l|c|c|c|c|c|}
\hline \multicolumn{1}{|c|}{ Name } & Number & $\begin{array}{c}\text { Power, } \\
\text { W }\end{array}$ & $\begin{array}{c}\text { Total } \\
\text { power, } \\
\text { W }\end{array}$ & $\begin{array}{c}\text { Number of } \\
\text { working } \\
\text { hours per day }\end{array}$ & $\begin{array}{c}\text { Energy consumption } \\
\text { for the estimated } \\
\text { period (year) kWh }\end{array}$ \\
\hline \multicolumn{6}{|c|}{ Household load } \\
\hline Lighting & 8 & 7 & 56 & 8 & 163 \\
\hline TV & 1 & 70 & 70 & 4 & 102 \\
\hline Fan & 1 & 60 & 60 & 3 & 65 \\
\hline Fridge & 1 & 67 & 67 & 5.8 & 141 \\
\hline \multicolumn{7}{|c|}{ Production load } \\
\hline Lighting & 16 & 7 & 112 & 8 & 327 \\
\hline Submersible pump & 1 & 245 & 245 & 3.4 & 273 \\
\hline Grain crusher & 1 & 750 & 750 & 1 & 338 \\
\hline Electric Bruder & 1 & 150 & 150 & 6 & 1713 \\
\hline \multicolumn{2}{c}{ Subtotal } & 1356 & 1510 & & \\
\hline
\end{tabular}


In summer, the peak load falls on the morning hours, which is associated with cooking for animals. Summer daily consumption is $3.71 \mathrm{kWh}$.

The increase in electricity consumption in winter is associated with an increase in the operating time of lighting, grain crushers and electric equipment. Winter daily consumption is $6.264 \mathrm{kWh}$.

The annual load schedule for individual farm users is shown in Figure 1.

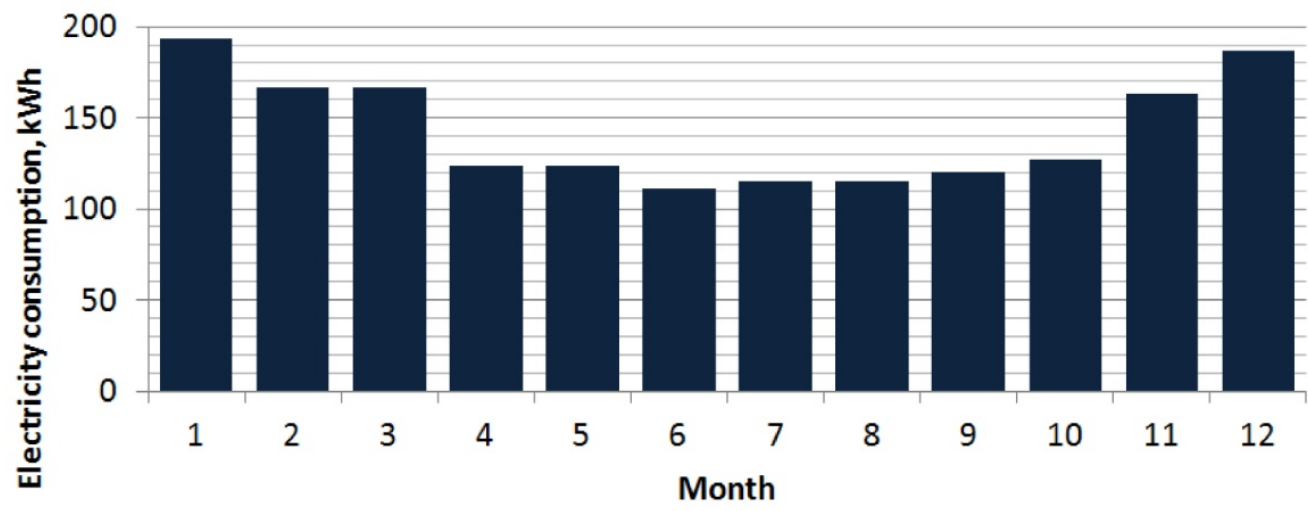

Fig. 1. Annual electricity consumption by an individual household

Based on the graph shown in Figure 3, the annual electricity consumption of an individual farm is $1.713 \mathrm{MWh}$.

To provide electricity to consumers of individual farms, it is advisable to use autonomous power supply systems based on alternative energy sources, such as wind and solar. This, in turn, will reduce the consumption of fuels and lubricants, reduce the cost of electricity generated, and extend the service life of the gas generator [1-6].

\section{Materials and methods}

To determine the parameters of elements of a combined autonomous power supply system, we will analyze the wind power potential and the potential of solar energy on the example of the Stavropol territory of the Russian Federation. Considering the Stavropol territory, we can distinguish the following areas, presented in Table 2, where the development of wind power is the highest priority.

Table 2

Specific technical wind energy resources

\begin{tabular}{|c|c|c|c|c|}
\hline \multirow{2}{*}{ District, city } & \multicolumn{4}{|c|}{ Installation height of the wind turbine, m } \\
\cline { 2 - 5 } & 8 & 15 & 30 & 45 \\
\cline { 2 - 5 } & \multicolumn{3}{|c|}{ Specific average annual technical energy resources, $\mathrm{kWh} \cdot \mathrm{m}^{-2}$} \\
\hline Turkmen & 34.84 & 70.752 & 132.392 & 175.004 \\
\hline Neftekumsky, Levokumsky & 10.72 & 24.924 & 56.414 & 85.894 \\
\hline Ipatovsky & 13.266 & 30.016 & 66.33 & 98.892 \\
\hline Trunovsky & 4.02 & 11.39 & 28,542 & 46.23 \\
\hline Andropov & 49.848 & 95.542 & 164.552 & 207.7 \\
\hline Stavropol & 145.37 & 211.988 & 278.452 & 310.076 \\
\hline
\end{tabular}

As it can be seen from Table 2, the regions of the Stavropol territory have a significant wind energy potential.

Stavropol territory is located in the center of the Caucasus, between $43^{\circ} 45^{\prime}-46^{\circ} 15^{\prime}$ North latitude and $40^{\circ} 50^{\prime}-45^{\circ} 40^{\prime}$ East longitude. The Central part is occupied by the Stavropol upland. This circumstance determines the amount of solar radiation per unit surface. Solar radiation, for example, for the city of Stavropol, located at the 45th parallel of the North latitude, is shown in Table 3.

Specific technical energy resources in the Stavropol territory are $140-220 \mathrm{~W} \cdot \mathrm{m}^{-2}$ at noon with clear sky. At the latitude of the Stavropol territory, mostly sunny weather is observed for about 
300 days a year (2200 hours). As it can be seen from Table 3, the Stavropol territory has a significant potential in the development of solar energy and is comparable to the Krasnodar territory.

Table 3

Emission of solar radiation for the city of Stavropol per month, $\mathrm{kWh} \cdot \mathrm{m}^{-2}$

\begin{tabular}{|c|c|c|c|c|c|c|c|c|c|c|c|c|c|}
\hline \multirow{2}{*}{ Position } & \multicolumn{12}{|c|}{ Month } & \multirow{2}{*}{ Annual } \\
\hline & 1 & 2 & 3 & 4 & 5 & 6 & 7 & 8 & 9 & 10 & 11 & 12 & \\
\hline $\begin{array}{l}\text { Horizontal } \\
\text { bar }\end{array}$ & 32 & 53 & 96 & 146 & 190 & 209 & 189 & 174 & 127 & 81 & 45 & 26 & 1371 \\
\hline $\begin{array}{l}\text { Vertical } \\
\text { panel }\end{array}$ & 62 & 76 & 99 & 103 & 97 & 92 & 91 & 112 & 123 & 116 & 86 & 52 & 1112 \\
\hline $\begin{array}{l}\text { Panel tilt } \\
45.0^{\circ}\end{array}$ & 56 & 78 & 122 & 161 & 187 & 197 & 184 & 189 & 164 & 124 & 80 & 46 & 1593 \\
\hline $\begin{array}{l}\text { Rotation } \\
\text { around the } \\
\text { polar axis }\end{array}$ & 69 & 96 & 157 & 218 & 268 & 293 & 269 & 276 & 229 & 164 & 102 & 57 & 2200 \\
\hline
\end{tabular}

Let us consider a simplified structural scheme of combined power supply to consumers, shown in Figure $2[7 ; 8]$.

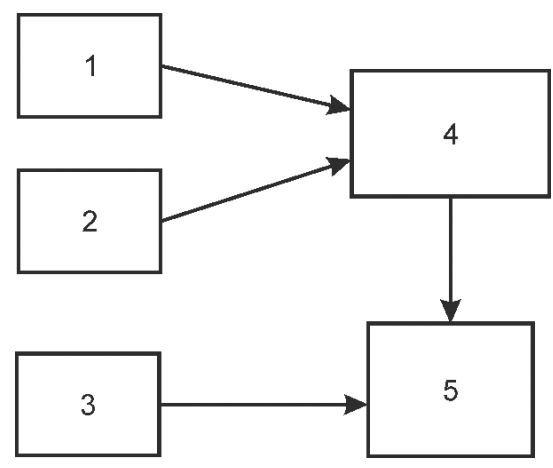

Fig. 2. Simplified block diagram of combined autonomous power supply to consumers:

1 - wind generator, 2 - solar panels, 3 - gas generator, 4 - power storage and distribution system, 5 - consumer

Energy from the wind generator and solar panels is accumulated in the storage system, or distributed through the inverter to the consumer. During periods of calm, alternative energy sources are supplied from the gas generator.

We will present a method for determining the parameters of elements of a combined autonomous power supply system, namely, a wind generator, solar panels, a gas generator, a storage system, and an inverter.

Specific technical energy resources of solar radiation can be determined from expression 1.

$$
W_{s p}=\int_{0}^{t} P_{s i}(t) \eta \cos (|\gamma-\alpha(t)|) \cos (|\delta-\beta(t)|) d t
$$

where $W_{s p}$ - power generation by solar panels, $\mathrm{Wh} \cdot \mathrm{m}^{-2}$;

$t$ - number of hours or days in the billing period;

$P_{s i}(t)$ - power of the solar installation at time t, W;

$\eta$ - efficiency of converting primary energy into electricity;

$\gamma$-zenith angle of installation of solar panels;

$\alpha(t)$ - zenith angle of the sun 's position at time t;

$\delta$ - azimuth angle of solar panel installation;

$\beta(t)$ - azimuth angle of the sun 's position at time $\mathrm{t}$.

Specific technical wind energy resources can be defined from expression 2. 


$$
W_{t r .}=0.61 \eta \int_{0}^{t} C_{p}(V) V^{3}(t) d t
$$

where $W_{t r}$ - wind power generation, $\mathrm{Wh} \cdot \mathrm{m}^{-2}$;

$C_{p}(V)$ - utilization factor of the luminous flux of the wind turbine;

$V^{3}(t)$ - wind speed at time $\mathrm{t}, \mathrm{m} \cdot \mathrm{s}^{-1}$.

Based on expressions 1 and 2, the production of specific technical energy resources on the example of the vicinity of Stavropol (coordinates 45 degrees 3 minutes North latitude, 41 degrees 59 minutes East longitude) of the Stavropol territory based on the data of the Stavropol hydrometeocenter, is presented by month of the year in Table 4 . The profile of the wind turbine is taken from the wind turbine WE-3000, the mounting height of the wind turbine $8 \mathrm{~m}$, nominal rated wind speed for a wind turbine is $7.5 \mathrm{~m} \cdot \mathrm{s}^{-1}$, the efficiency of energy conversion (synchronous generator) wind into electrical energy amounted to $80 \%$ of maximum utilization of the wind flow 0.35 solar panel is adopted BSP $32-100 \mathrm{~F}$, the efficiency of solar panel is $15 \%$, and zenith angle $45^{\circ}$, azimuth $180^{\circ}$.

Using equations 1 and 2, it is possible to determine the specific technical wind-solar energy characteristics for any region of Russia.

\section{Specific technical energy resources, $\mathrm{kWh} \cdot \mathrm{m}^{-2}$}

Table 4

\begin{tabular}{|c|c|c|}
\hline Month & The sun & Wind \\
\hline January & 11.51 & 14.97 \\
\hline February & 13.6 & 12.46 \\
\hline March & 16.38 & 11.93 \\
\hline April & 19.28 & 12.66 \\
\hline May & 23.02 & 11.4 \\
\hline June & 22.28 & 9.12 \\
\hline July & 23.91 & 9.76 \\
\hline August & 23.47 & 11.62 \\
\hline September & 20.14 & 11.91 \\
\hline October & 16.38 & 13.39 \\
\hline November & 10.28 & 12.48 \\
\hline December & 8.85 & 13.64 \\
\hline Year & 209.15 & 145.37 \\
\hline
\end{tabular}

Table 4 shows the average monthly electricity generation per unit area of the wind wheel and solar panel. Let us present these data in graphical form in Figure 3.

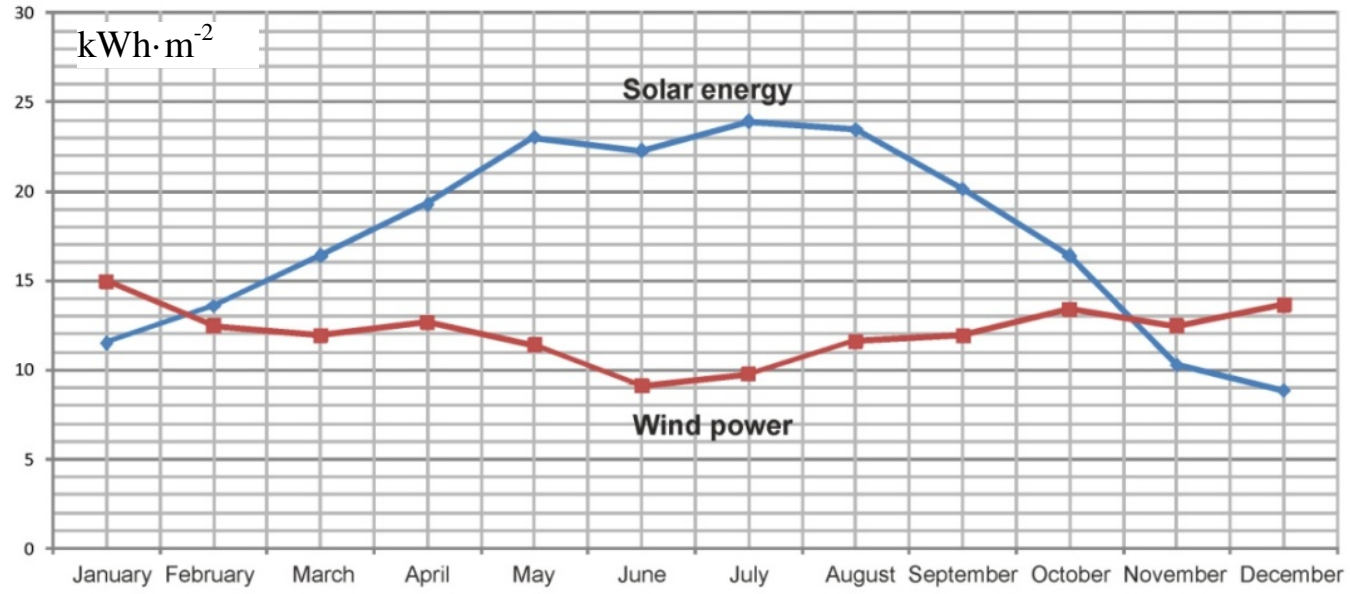

Fig. 3. Average monthly electricity generation per unit area of a wind turbine and solar panel for the surrounding area of Stavropol 
As it can be seen from Figure 3, for the environment of Stavropol, there is a more intensive generation of electricity by solar panels in summer and a more intensive generation of electricity by wind energy in winter per unit area of the generated surface, from which we should choose the parameters of the wind generator and solar panels depending on the load parameters.

Based on the obtained graphs of electricity generation, we will determine the ratio of generated areas for a wind generator and solar panels, presented from the expressions below.

$$
k_{v g}=\left(1-\frac{W_{v t}}{W_{v t}+W_{s t}}\right) \cdot 100 \% ; k_{s p}=\left(1-\frac{W_{s t}}{W_{v t}+W_{s t}}\right) \cdot 100 \%
$$

Based on expression 3 and taking into account the average monthly electricity generation in Figure 3, the rational ratio of generated areas for a wind generator is $59 \%$, for solar panels $41 \%$.

The total area of generated surfaces is determined from expression 4

$$
S=\frac{W_{p}}{\left(W_{w t}+W_{s t}\right) / 2}
$$

where $S$ - total area of electricity -generated surfaces, $\mathrm{m}^{2}$;

$W_{p}$ - electricity consumed by consumers of individual subsidiary farms, Wh.

By substituting the values in expression 4, we get the total area of generated surfaces of $9.66 \mathrm{~m}^{2}$, this value is rounded to $10 \mathrm{~m}^{2}$.

The energy generated by generating areas should be equal to the energy consumption of an individual farm. Taking into account the uneven schedule of annual electricity consumption, the lack of electricity generation by alternative energy sources should be made up by generating electricity by a gasoline generator. Thus, the target function can be written as

$$
W_{v t}+W_{s t}+W_{b g} \Rightarrow W_{p}
$$

where $W_{b g}-$ electricity generated by the gas generator, Wh.

In accordance with the annual electricity consumption schedule shown in Figure 1, taking into account expressions 3-5, we will determine the parameters of the wind generator and solar panels.

The power of the wind turbine generator is determined from expression 6

$$
P_{g}=0.481 V_{p}^{3} D^{2} C_{p} k_{h} \eta_{g}
$$

where $P_{g}$ - capacity of the generator, W;

$V_{p}$ - working wind speed, $\mathrm{ms}^{-1}$;

$D$ - wind turbine diameter, $\mathrm{m}$;

$C_{p}$ - luminous flux utilization factor;

$k_{h}$ - wind turbine installation height coefficient;

$\eta_{g}$ - efficiency of the generator.

The capacity of the battery is determined from expression 7.

$$
E_{a b}=\frac{P_{s} t}{24 V\left(1-C_{r}\right)}
$$

where $E_{a b}$ - battery capacity, Ah;

$P_{s}$ - daily electricity consumption, Wh;

$t$ - period of power supply to consumers due to the energy stored in the battery, h;

$V$ - battery voltage, $\mathrm{V}$;

$C_{r}$ - maximum permissible depth of discharge of the battery.

\section{Results and discussion}

After making the necessary calculations, we obtain the area of the wind turbine $6 \mathrm{~m}^{2}(60 \%$ of generated electricity area) that corresponds to the radius of the propeller of 1.4 meters, area of solar panels $4 \mathrm{~m}^{2}$ (40\% of the generated electricity area), while power output will be $1708.82 \mathrm{kWh}$ 
(836 kWh due to solar energy (49\%), $872 \mathrm{kWh}$ due to wind energy $(51 \%))$. Figure 4 shows a graph of electricity consumption and generation.

$\mathrm{kWh} / \mathrm{m}^{2}$

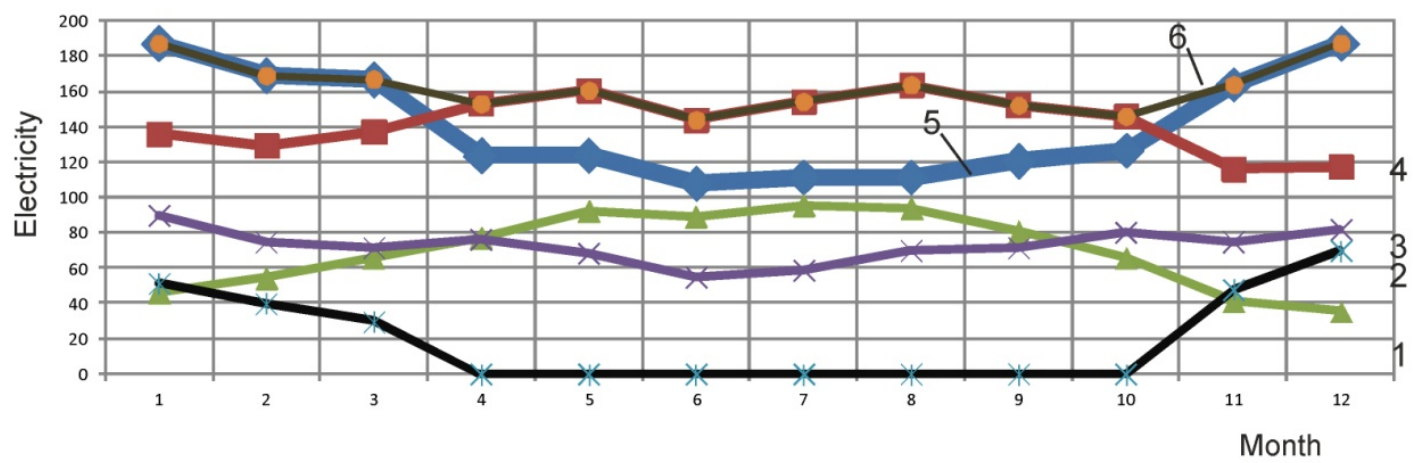

Fig. 4. Graph of generation and consumption of electricity: 1 - electricity generation solar panels; 2 - power generation by the generator 3 - electricity generation wind turbine; 4 - total power generation with alternative sources of energy 5 - electricity consumption of individual farms; 6 - generation of electricity combined autonomous power supply system

Since the annual load schedule shown in Figure 1 is not linear, electricity generation from alternative energy sources is not sufficient in winter. Compensation for this amount of electricity is carried out by the operation of the gas generator, so, based on Figure 4, the generation of electricity by a combined autonomous power supply system (curve 6) will cope with or lie above the electricity consumption schedule (curve 5).

Based on the above, the following quantitative values of electricity generation are obtained: the total output of the combined autonomous power supply system is $1950.7 \mathrm{kWh}(100 \%)$, solar panels $836.6 \mathrm{kWh}(42.9 \%)$, the wind generator $872.2(44.7 \%)$, the gasoline generator $241.9 \mathrm{kWh}(12.4 \%)$.

The power of solar panels, based on an area of $4 \mathrm{~m}^{2}$, is $600 \mathrm{~W}$.

For the operating speed of the windmill $7.5 \mathrm{~ms}^{-1}$, which corresponds to the profile of the WE-3000 windmill, the power of the synchronous generator is $445 \mathrm{~W}$, the profile of the WE-3000 wind wheel, the diameter of the wind wheel is $2.8 \mathrm{~m}$, the wind flow utilization factor is 0.35 .

The gas generator must provide the possibility of starting asynchronous electric motors of the electrical equipment of the individual farm under consideration. The rated power of the asynchronous motor is $750 \mathrm{~W}$, the starting current multiplicity is 5.5 . When using a soft-start device, this indicator is reduced by half to 2.75 . The power of the power source $2.06 \mathrm{~kW}$ is required to start the grain crusher engine, choosing a gasoline generator with a capacity of $2.2 \mathrm{kVA}$.

The maximum daily electricity consumption is observed in winter and it is $6264 \mathrm{Wh}$. To ensure the operation of consumers from batteries for 8 hours, the battery capacity is $232 \mathrm{Ah}$, the voltage $12 \mathrm{~V}$.

The power of the inverter is determined based on the maximum load, taking into account the above, $2.2 \mathrm{~kW}$ is accepted.

\section{Conclusions}

1. For supplying power to consumers of an individual subsidiary farm, the installed capacity of which is $1.51 \mathrm{~kW}$, summer daily consumption of $3.71 \mathrm{kWh}$, winter daily consumption of electricity $6.264 \mathrm{kWh}$, annual electricity consumption of $1713 \mathrm{kWh}$, it is advisable to carry it out with the help of an autonomous power supply system based on wind and solar energy, as a guaranteed backup power source, it is advisable to use a gasoline generator.

2. Districts of the Stavropol territory have a high wind energy potential, specific technical wind energy resources at the height of the wind wheel installation at 8 meters are up to $145 \mathrm{kWh} \cdot \mathrm{m}^{-2}$ per year, at the height of the wind wheel installation at 45 meters, this indicator increases to 310 $\mathrm{kWh} \cdot \mathrm{m}^{-2}$ per year. Mostly sunny weather in the regions of the Stavropol territory (Stavropol) is observed about 300 days a year (2200 hours), technical helium resources are $209 \mathrm{kWh} \cdot \mathrm{m}^{-2}$ per year. 
3. The combined wind-solar system of the autonomous power supply is adopted with the following parameters: the area of the wind engine is $6 \mathrm{~m}^{2}$, which corresponds to the radius of the wind wheel of $1.4 \mathrm{~m}$, the area of solar panels is $4 \mathrm{~m}^{2}$. With the non-linearity graph of the annual loads of consumers the following quantitative values of power production are obtained: total output of the combined system of the autonomous power supply $1950.7 \mathrm{kWh}(100 \%)$, solar panels 836.6 $\mathrm{kWh}(42.9 \%)$, wind turbine $872.2(44.7 \%)$, the gasoline generator $241.9 \mathrm{kWh}(12.4 \%)$. The estimated power of the synchronous generator was $445 \mathrm{~W}$, solar panels $-600 \mathrm{~W}$, and the gasoline generator $-2.2 \mathrm{~kW}$.

\section{References}

[1] Razmjoo A., Shirmohammadi R., Davarpanah A., Pourfayaz F., Aslani A. Stand-alone hybrid energy systems for remote area power generation. Energy Reports vol. 5, 2019. pp. 231-241.

[2] Samikannu R., Sampath Kumar V., Diarra B., Ravi R. Cost optimization and development of hybrid energy systems for rural areas in Ethiopia with a balance of their energy need and resources availability (a case study-on TulUDIMTU). Journal of Testing and Evaluation vol. 47(6), 2019, JTE20180462.

[3] Sun W., Harrison G.P. Wind-solar complementarity and effective use of distribution network capacity. Applied Energy vol. 247,2019, pp. 89-101.

[4] Al-Dousari A., Al-Nassar W., Al-Hemoud A, Al-Dousari N., Ahmed M. Solar and wind energy: Challenges and solutions in desert regions. Energy, vol. 176, 2019, pp. 184-194.

[5] Zhang X., Lu N., Jiang H., Yao L. Evaluation of Reanalysis Surface Incident Solar Radiation Data in China. Scientific Reports. 2020, 10(1), 3494.

[6] Shayeghi H., Hashemi Y. Potentiometric of the renewable hybrid system for electrification of gorgor station. 2020, Journal of Operation and Automation in Power Engineering 8(1), pp. 1-14.

[7] Pat. 2680642 Russian Federation, IPC F03D 9/00, F03D 9/11, F03D 7/00, H02S 10/12 wind-solar installation Autonomous power supply / Nikitenko G. V., Konoplev V. E., Salpagarov K. V., Konoplev, P. V., Bobryshev V. A., Lysakov A. A.; applicant and patent holder FGBOU IN Stavropol GAU. No. 2018103296; application. 29.01.18; publ. 25.02.19, Byul. No. 6.

[8] Pat. 2680642 Russian Federation, IPC H02K 1/27, H02K 21/12, H02K 16/02 Synchronous generator with dual magnetic system / Nikitenko G. V., Konoplev V. E., Salpagarov K. V., Konoplev, P. V., Bobryshev, A. V.; applicant and patent holder FGBOU IN Stavropol GAU. No. 2016152824; application. 30.12.16; publ. 25.01.18, Byul. No. 3. 